\title{
PEMEROLEHAN BAHASA ANAK TUNARUNGU USIA 12-15 TAHUN DI PANTI SOSIAL BINA RUNGU WICARA MELATI
}

\author{
Deasy Wahyu Hidayati
}

\author{
Program Studi Pendidikan Bahasa dan Sastra Indonesia \\ FKIP Universitas Muhammadiyah Prof. DR. HAMKA \\ Jakarta \\ hidayatideasy@gmail.com
}

Naskah masuk: 24-10-20, direvisi: 30-01-20, diterima: 21-02-20, dipublikasi: 30-04-20

\begin{abstract}
Abstrak: Penelitian ini bertujuan untuk mengetahui bagaimana pemerolehan bahasa (bidang fonologi, sintaksis, semantik) pada anak tunarungu usia 12-15 tahun di panti sosial bina rungu wicara melati. Metode yang digunakan dalam penelitian ini adalah metode observasi dengan pendekatan kualitatif. Dalam penelitian ini peneliti merekam ujaran maupun tingkah laku anak saat berujar, baik secara visual maupun auditori kemudian data tersebut ditranskripsikan dan diamati bentuk visualnya. Penelitian ini dilaksanakan di Panti Sosial Bina Rungu Wicara Melati yang berada di Jalan Gebang Sari No. 38 Bambu Apus Jakarta Timur dengan waktu yang digunakan oleh peneliti adalah $4 \times 30$ menit. Berdasarkan hasil penelitian, maka pemerolehan bahasa anak tunarungu usia 12-13 tahun di panti sosial bina rungu wicara adalah bidang fonologi, anak tunarungu usia 12-13 tahunlebih sering mengabaikan huruf konsonan karena artikulasi berada di dalam rongga mulut sehingga sulit untuk dipelajari oleh anak tunarungu sedangkan vokal lebih mudah untuk ditiru karena vokal mengandalkan gerak bibir yang mudah untuk dilihat. Pada bidang sintaksis bahwa anak-anak tunarungu usia 12-13 tahun telah mengenal subjek, predikat, objek, dan keterangan. Saat proses menyusun kalimat-kalimat tersebut, mereka memang membutuhkan waktu yang cukup lama namun dari hasil yang dilihat, mereka sudah tampak bahwa mereka telah memahami susunan kalimat yang benar. Sedangkan bidang semantik, anak tunarungu usia 12-13 tahun dalam tingkat pemahaman sebuah makna dari nama-nama organ tubuh, mereka belum sepenuhnya memahami. Butuh pembelajaran lagi dalam hal tersebut.
\end{abstract}

Kata kunci: Pemerolehan Bahasa, Anak Tunarungu

\begin{abstract}
This study aims to find out how language acquisition (phonology, syntax, semantics) in deaf children aged 12-15 years in social institutions of deaf speech and jasmine. The method used in this research is the observation method with a qualitative approach. In this study, researchers recorded the speech and behavior of children when speaking, both visually and auditory then the data is transcribed and observed in its visual form. This research was conducted at the Social Institution of the Deaf Wati Melati in Jalan Gebang Sari No. 38 Bambu Apus East Jakarta with the time used by researchers is $4 \times 30$ minutes. Based on the results of the study, the acquisition of language of deaf children aged 12-13 years in social institutions for deaf speech is phonology, deaf children aged 12-13 years more often ignore consonantal letters because articulation is in the oral cavity so it is difficult to learn by deaf children while vowels are easier to imitate because vowels rely on lip movements that are easy to see. In the field of syntax that children with hearing impairment aged 12-13 years are familiar with the subject, predicate, object, and description. When the process of composing these sentences, they do require a long time but from the results seen, they already seem that they have understood the correct sentence structure. Whereas in the semantic field, deaf children aged 12-13 years in the level of understanding of the meaning of the names of organs, they do not fully understand. Need more learning in this regard.
\end{abstract}

Keywords: Language Acquisition, Deaf Children 


\section{PENDAHULUAN}

Pemerolehan bahasa merupakan proses seorang anak dalam penguasaan bahasa. Hal ini dikemukakan pula oleh Dardjowidjojo (2014: 225) bahwa pemerolehan dipakai untuk padanan istilah Inggris acquisition yakni proses penguasaan bahasa yang dilakukan oleh anak secara natural pada waktu dia belajar bahasa ibunya (native language). Pemerolehan bahasa merupakan salah satu hal yang menarik untuk dikaji karena menyangkut berbagai aspek perkembangan anak seperti pada bidang psikolinguistik.

Pemerolehan bahasa yang baik didukung oleh dua indra yaitu pendengaran dan penglihatan. Apabila salah satu tidak dapat berfungsi dengan baik maka bahasa tidak dapat berjalan dengan lancar.

Pada konkritnya, anak-anak normal mendapatkan stimulus dari dua panca indra, yaitu penglihatan dan pendengaran. Bagi anak-anak tunarungu masalahnya menjadi lebih kompleks karena sarana utama menerima bahasa secara normal dan mudah yang mereka miliki terganggu.

Anak tunarungu dalam perkembangannya mendapatkan hambatanhambatan yang mempengaruhi pribadi dan penyesuaian diri terutama efek dari keadaan kurang mendengar. Adapun Amin (1991: 10) mengemukakan bahwa anak tunarungu adalah mereka yang mengalami kekurangan atau kehilangan kemampuan mendengar yang disebabkan oleh kerusakan atau tidak berfungsinya sebagian atau seluruh organ pendengaran yang mengakibatkan hambatan dalam perkembanganya sehingga memerlukan bimbingan pendidikan khusus. Kurangnya pendengaran mempengaruhi pula proses berbahasa. Dalam memperoleh bahasa baik fonologi, sintaksis, maupun semantik mereka mempunyai karakteristik tersendiri dibanding anak yang mempunyai pendengaran normal.
Berdasarkan observasi awal, anak tunarungu juga mendapat kesulitan dalam bermasyarakat. Hal ini karena tingkah laku masyarakat yang cenderung menganggap mereka orang yang sulit diajak berkomunikasi sehingga untuk berhubungan dengan mereka memerlukan waktu dan kesabaran yang lebih banyak daripada berhubungan dengan orang normal.

Berdasarkan hal ini, peneliti ingin mengetahui proses pemerolehan bahasa anak tunarungu. Oleh karena itu, peneliti merasa tertarik untuk melakukan penelitian mengenai "Pemerolehan Bahasa Anak Tunarungu Usia 12-15 Tahun di Panti Sosial Bina Rungu Wicara (PSBRW) Melati”.

\section{KAJIAN TEORI \\ Pengertian Pemerolehan Bahasa}

Bahasa merupakan alat komunikasi yang digunakan oleh manusia untuk berinteraksi dengan sesamanya. Melalui bahasa, manusia bisa berbagi ilmu pengetahuan, berbagi ide, memberikan informasi dan lain-lain. Dengan kata lain, manusia akan mampu menguasai atau memperoleh bahasa selama dia hidup, tumbuh dan berkembang dalam suatu masyarakat dimanapun dia berada yang selalu menggunakan bahasa. Seperti yang dikemukakan oleh Brown (2008: 6) bahwa bahasa itu dipakai untuk berkomunikasi yang beroperasi dalam sebuah komunitas atau budaya wicara yang pada dasarnya bahasa itu untuk manusia walaupun bisa jadi tak hanya manusia. Namun tentulah ada proses yang dilalui oleh manusia dalam memperoleh bahasa tersebut.

Proses pemerolehan bahasa terdapat beberapa perbedaan pendapat dikalangan ahli bahasa. Ada yang berpendapat bahwa proses pemerolehan bahasa itu bersifat Nurture dan ada yang berpendapat bahwa pemerolehan bahasa 
tersebut bersifat Nature. Para pendukung pemerolehan bahasa bersifat nurture pada umumnya adalah para ahli bahasa yng berasal dari aliran Behaviorisme sedangkan para pendukung pemerolehan bahasa berifat nature umumnya adalah para ahli yang menganut aliran navitisme. Oleh karena itu pembahasan mengenai proses pemerolehan bahasa ini berkaitan dengan kedua aliran behaviorisme dan nativisme.

$$
\text { Dardjowidjojo (2014: }
$$

menambahkan bahwa pemerolehan bahasa yang bersifat nurture itu adalah pemerolehan bahasa yang ditentukan oleh alam lingkungan. Pendapat ini sejalan dengan aliran behaviorisme yang meyakini bahwa setiap anak yang dilahirkan ke dunia ini disertai dengan tabula rasa yaitu semacam piring kosong tanpa suatu apapun, kemudian sejalan dengan pertumbuhan dan perkembangan yang dilaluinya dalam lingkungannya, maka piring tersebut akan terisi dengan sendirinya, termasuk bahasa. Bahasa tersebut akan tumbuh dan berkembang sejalan dengan pertumbuhan dan perkembangan anak tadi.

\section{Proses Pemerolehan Bahasa \\ Pemerolehan Bahasa dalam Bidang Fonologi}

Secara etimologi kata fonologi berasal dari gabungan 'fon' yang berarti 'bunyi' dan 'logi' yang berarti 'ilmu'. Jadi dapat dikatakan, fonologi adalah ilmu sebagai bagian dari kajian linguistik yang mempelajari, membahas, membicarakan dan menganalisis bunyi-bunyi bahasa yang diproduksi oleh alat ucap manusia (Chaer, 2009: 1).

Dihubungkan pada pemerolehan bahasa, saat dilahirkan, anak hanya memiliki sekitar $20 \%$ dari otak dewasanya, berbeda dengan binatang yang sudah memiliki sekitar $70 \%$. Karena perbedaan inilah maka binatang sudah dapat melakukan banyak hal setelah lahir, sedangkan manusia hanya bisa menangis dan menggerak-gerakkan badannya. Pada usia 6 minggu, anak mulai mengeluarkan bunyi-bunyi yang mirip dengan bunyi konsonan atau vokal.

Proses mengeluarkan bunyi-bunyi seperti ini dinamakan cooing, yang telah diterjemahkan menjadi dekutan (Dardjowidjojo, 2014: 244). Anak mendekutkan bermacam-macam bunyi yang belum jelas identitasnya.

Pada sekitar usia 6 bulan, anak mulai mencampur konsonan dengan vokal sehingga membentuk apa yang dalam bahasa Inggris dinamakan babbling, yang telah diterjemahkan menjadi celotehan. Celotehan dimulai dengan konsonan yang keluar pertama adalah konsonan bilabial hambat dan bilabial nasal. Vokalnya adalah /a/ dengan demikian strukturnya adalah CV (Consonant Vocal) dan ini diulang sehingga muncullah struktur kata.

Ketika berumur satu tahun, mereka berusaha menirukan kata-kata dan mengucapkan suara-suara yang mereka dengar di sekitar mereka, dan kira-kira pada saat itulah mereka mengucapkan "kata-kata" pertama mereka. Pada usia 18 bulan, katakata itu berlipat ganda dan mulai muncul dalam "kalimat" dua atau tiga kata, umumnya disebut ujaran-ujaran "telegrafis (bergaya telegram)".

Makin banyak kata yang diucapkan setiap hari maka semakin banyak kombinasi kalimat yang dituturkan. Usia 2 tahun, anakanak memahami bahasa yang lebih canggih dan kecakapan bertutur merekapun mengembangkan.bahkan dapat membentuk pertanyaan dan pernyataan.

\section{Pemerolehan Bahasa dalam Bidang Sintaksis}

Dalam bidang sintaksis Chaer (2009: 3) mengungkapkan bahwa sintaksis membicarakan penataan dan pengaturan kata-kata ke dalam satuan-satuan yang lebih 
besar, yang disebut satuan-satuan sintaksis yakni kata, frase, klausa, kalimat dan wacana. Pada aspek ini anak memulai berbahasa dengan mengucapkan satu bagian kata yang sebenarnya adalah kalimat penuh tetapi karena dia belum dapat mengatakan lebih dari satu kata dari seluruh kalimat itu atau dikenal dengan Ujaran Satu Kata USK (one word utterance).

Sekitar umur 2 tahun, anak mulai mengeluarkan Ujaran Dua Kata UDK (two word utterance). Anak mulai dengan dua kata yang diselingi jeda sehingga seolaholah dua kata itu terpisah. Ciri lain UDK adalah kedua kata ini merupakan kata-kata dari kategori utama, verba, ajektiva, atau bahkan adverbial. Belum ada kata fungsi seperti ; di, yang, dan, dsb. UDK juga sering disebut ujaran telegrafik (telegraphic speech).

\section{Pemerolehan Bahasa dalam Bidang Semantik}

Menurut beberapa ahli, perkembangan kanak-kanak kata itu satu demi satu sampai semua fitur semantik dikuasai, seperti yang dikuasai oleh orang dewasa. Akhirnya Clark dalam Dardjowidjojo (2014: 245) secara umum menyimpulkan perkembangan pemerolehan semantik ini ke dalam 4 tahap sebagai berikut :

a. Tahap penyempitan makna kata.

Tahap ini berlangsung antara usia 1-1,5 tahun. Anak menganngap satu benda yang disebut "gukguk" hanyalah anjing yang dipelihara di rumah saja.

b. Tahap generalisasi berlebihan

Tahap ini antara usia 1,6 - 2,5 tahun, anak-anak akan mulai menggeneralisasikan makna suatu kata secara berlebihan. Jadi yang dimaksud gukguk adalah semua binatang berkaki empat.

c. Tahap medan semantik.

Tahap ini antara usia 2,6 -5,0 tahun. Pada tahap ini anak mulai mengelompokkan kata-kata yang berkaitan ke dalam satu medan semantik. Kalau pada mulanya kata anjing berlaku untuk semua binatang berkaki 4, namun setelah mereka mengenal kambing, harimau, maka anjing berlaku untuk anjing saja.

d. Tahap generalisasi

Tahap ini setelah anak-anak berusia 5 tahun. Mereka telah mulai mampu mengenal benda-benda yang sama dari sudut persepsi, bahwa benda-benda. Itu mempunyai fitur-fitur semantik yang sama. Jadi ketika berusia 5 - 6 tahun. Mereka telah mampu mengenal yang dimaksud dengan hewan.

\section{Anak Tunarungu \\ Pengertian Tunarungu}

Tunarungu adalah seseorang yang mengalami kekurangan atau kehilangan kemampuan mendengar baik sebagian atau seluruhnya yang diakibatkan karena tidak berfungsinya sebagian atau seluruh alat pendengaran, sehingga ia tidak dapat menggunakan alat pendengaranya dalam kehidupan sehari-hari yang membawa dampak terhadap kehidupannya secara kompleks. Kerusakan yang terjadi pada pendengaran dapat berupa terjadinya benturan di kepala yang mengakibatkan rusaknya pendengaran, kerusakan saraf, cederanya gendang telinga, dan infeksi telinga.

Menurut Donald F. Morees dalam Murni Winarsih (2007: 1) mendefinisikan tunarungu sebagai berikut:

Hearing impairment a generic term indicating a hearing disability that may range in severty from mild to profound it concludes hearing disability preclude succesfull processing of linguistic information through audition, with or without a hearing aid. A hard of hearing is one who generally with use of hearing 
aid, hs residual hearing sufficient to enable succesfull processing og linguistic information through audition.

Dapat disimpulkan bahwa tunarungu adalah suatu istilah yang digunakan untuk seseorang yang memiliki kesulitan atau kehilangan dalam pendengaran yang disebabkan oleh tidak berfungsinya lagi sebagian atau seluruh alat pendengarannya.

\section{Klasifikasi Tunarungu}

Klasifikasi tunarungu memiliki pandangan yang berbeda di setiap para ahli, seperti Streng dalam Somad dan Hernawati sebagai berikut:

1. Mild Loses, yaitu kehilangan kemampuan mendengar 20-30 dB yang memiliki ciri- ciri :

a. Sukar mendengar percakapan yang lemah.

b. Menuntut sedikit perhatian khusus dari sistem sekolah tentang kesulitannya.

c. Perlu latihan membaca ujaran dan perlu diperhatikan perkembangan penguasaan perbendaharaan kata.

2. Marginal Loses, yaitu kehilangan kemampuan mendengar 30-40 dB yang memiliki ciri-ciri sebagai berikut

a. Mengerti percakapan biasa pada jarak satu meter.

b. Mereka sulit menangkap percakapan dengan pendengaran pada jarak normal dan kadang-kadang mereka mendapat kesulitan dan menangkap percakapan kelompok.

c. Mereka akan sedikit mengalami kelainan bicara dan perbendaharaan kata yang terbatas. d. Kebutuhan dalam program pendidikan antara lain belajar membaca, penggunaan alat bantu dengar, latihan bicara, latihan artikulasi dan perhatian dalam perkembangan perbendaharaan kata.

3. Moderat loses, yaitu kehilangan kemampuan mendengar 40-60 dB yang memiliki ciri-ciri sebagai berikut :

a. Mereka mengerti percakapan keras pada jarak satu meter.

b. Perbendaharaan kata terbatas

4. Severa loses, yaitu kehilangan kemampuan mendengar 60-70 dB. Memiliki ciri-ciri :

a. Mereka masih biasa mendengar suara keras dari jarak yang dekat misalnya klakson mobil dan lolongan anjing.

b. Mereka diajar dalam suatu kelas khusus untuk anak-anak tunarungu.

c. Diperlukan latihan membaca ujaran dan pelajaran yang dapat mengembangkan bahasa dan bicara dari guru kelas khusus.

5. Profound loses, yaitu kehilangan kemampuan mendengar $75 \mathrm{~dB}$ keatas. Memiliki ciri : Mendengar suara yang keras pada jarak 1 inci $(2,24 \mathrm{~cm})$ atau sama sekali tidak mendengar walaupun menggunakan alat bantu dengar (Somad dan Hernawati, 1969: 20-33)

Berbeda pula dengan Putranto (2015: 227-228) yakni dilihat dari tingkat kerusakan maka tunarungu dapat dibedakan menjadi lima kelompok, yaitu sangat ringan (27-40 desibel), ringan (41-55 desibel), sedang (56-70 desibel), berat (71-90 desibel), dan sangat berat (91 atau lebih tinggi). 


\section{METODE}

Metode yang digunakan dalam penelitian ini adalah metode observasi dengan pendekatan kualitatif. Sesuai yang dikatakan oleh Dardjowidjojo (2014: 228), metode obsevasi yakni data diperoleh dengan merekam ujaran maupun tingkah laku anak saat berujar, baik secara visual maupun auditori kemudian data tersebut ditranskripsikan dan diamati bentuk visualnya akhirnya diolah untuk ditemukan kesimpulan-kesimpulannya.

Seperti dokumentasi dapat berupa hasil kerja/tugas anak, catatan pribadi anak tunarungu, selanjutnya wawancara kepada pihak yayasan yang menjadi orangtua asuh anak-anak tunarungu selama di yayasan Panti Sosial Bina Rungu Wicara Melati.

\section{HASIL DAN PEMBAHASAN}

Pada penelitian ini, peneliti meneliti pemerolehan bahasa anak tunarungu usia 12-15 tahun di panti sosial tuna rungu wicara (PSBRW) Melati yang terletak di jalan gebang sari nomor 38 bambu apus Jakarta Timur. Jumlah seluruh anak tunarungu yang berada di PSBRW Melati ada 75 anak, terdiri dari usia 10-15 tahun berjumlah 2 orang, usia 16-20 tahun berjumlah 34 orang, usia 21-25 tahun berjumlah 28 orang, dan usia diatas 26 tahun berjumlah 11 orang.

PSBRW Melati hanya mendidik anakanak tunarungu selama 2-3 tahun, setelah anak-anak sudah menjalani pendidikan atau pembelajaran di PSBRW maka mereka akan dipulangkan kepada orang tuanya. Banyak keterampilan yang dimiliki PSBRW Melati, seperti keterampilan menjahit, gerabah, tata boga, salon, komputer, kerajinan tangan, serta ekonomi produktif (burung sangkar).

Peneliti hanya meneliti pemerolehan bahasa anak tunarungu di usia 12-15 tahun yang terdiri dari 2 anak, yakni berinisial RM berusia 15 tahun dan NWA berusia 13 tahun.
RM atau akrab dipanggil RM, lahir di Canti, Lampung Selatan pada tanggal 24 agustus 1999. RM lahir dari ayah yang bernama Tabrani dan ibu bernama Maria Rantawati. la adalah anak pertama dari dua bersaudara. RM mengalami tunarungu sejak lahir. Berdasarkan hasil dari uji lab yang telah dilakukan pihak PSBRW Melati bahwa RM mengalami tunarungu sejak kecil dan dapat diklasifikasikan dalam kelompok berat yakni $78,75 \mathrm{db}$. la sudah belajar di PSBRW sejak 1 tahun dan saat ini RM sudah mampu berbahasa dan berinteraksi sosial dengan baik. RM merupakan salah seorang anak tunarungu yang pandai dan cerdas, ia pernah menjuarai lomba komputer dengan peserta seluruh anak tunarungu seJabodetabek.

NWA atau akrab dipanggil NWA, lahir di Bekasi pada tanggal 21 Agustus 2001. NWA lahir dari ayah yang bernama I Wayan Wijaya dan ibu bernama Suci Rahayu. NWA merupakan anak pertama dari dua bersaudara. Sama halnya dengan RM, NWA mengalami tunarungu sejak lahir. Belum adanya tes yang dilakukan oleh pihak PSBRW dikarenakan NWA baru mendaftar di PSBRW sekitar 2-3 bulan. Namun, orang tua asuh NWA di PSBRW yang bernama Sherly, bisa mengklasifikasikan NWA termasuk anak tunarungu dalam kelompok ringan. Orang tua asuh melihat dari keseharian serta interaksi yang dilakukan oleh NWA bersama kerabat-kerabatnya.

Dari hasil observasi yang telah dilakukan, peneliti dapat menyimpulkan dari tiga aspek pemerolehan bahasa yakni fonologi, sintaksis dan semantik bahwa dilihat dari :

a. Bidang Fonologi

Sebelum RM dan NWA mengucapkan kata demi kata, peneliti melatih mereka untuk mengucapkan bunyi konsonan dan vokal satu per satu. Kemudian mengkombinasikan beberapa 
bunyi menjadi satu kata seperti kata /biru/. Dapat disimpulkan bahwa kemampuan RM dan NWA dalam menghasilkan kata-kata sudah mulai sempurna. Namun dapat diketahui bahwa anak tunarungu mampu mengucapkan huruf vokal dengan baik dibandingkan huruf konsonan seperti mengucapkan kata;

$$
\begin{array}{ll}
\text { /marah/ } & \rightarrow \text { /ma la/ } \\
\text { /pulau/ } & \rightarrow \text { /u lau/ } \\
\text { /kakek/ } & \rightarrow \text { ta te/ } \\
\text { /kue/ } & \rightarrow / \mathrm{u} \mathrm{e/}
\end{array}
$$

Peneliti menyadari bahwa cara belajar anak tunarungu melalui keterwajahan, mereka melihat bibir teman berbahasanya. Oleh karena itu konsonan lebih sering diabaikan karena artikulasi berada di dalam rongga mulut sehingga sulit untuk dilihat atau dipelajari oleh anak tunarungu sedangkan vokal lebih mudah untuk ditiru karena vokal mengandalkan gerak bibir yang mudah untuk dilihat. Adapun bunyi-bunyi konsonan yang sulit untuk mereka ucapkan adalah /k/, /q/, /w/, /h/, /z/, /y/, $/ \mathrm{x} / \mathrm{,} / \mathrm{s} /, \mathrm{r} /$.

b. Bidang Sintaksis

Pada aspek ini, peneliti membuat tes yang mudah dilaksanakan. Peneliti membuat potongan-potongan kertas yang didalamnya terdapat penggalan kata-kata. Anak-anak diharapkan dapat menyusun kalimat dengan kemampuan yang telah mereka miliki.

Kalimat yang telah dihasilkan oleh RM dan NWA dengan keterangan bahwa poin 1 - 2 memilih satu kata yang tepat dan poin 3-7 menyusun kalimat:

1. Motor baru

2. Rumah besar

3. Kakak membaca novel

4. Nenek membawa kue

5. Ibu memasak nasi

6. Ayah mencuci mobil baru
7. Bimo bermain bola di lapangan

Berdasarkan tes ini dapat disimpulkan bahwa RM dan NWA telah mengenal subjek, predikat, objek, dan keterangan. Saat proses menyusun kalimat-kalimat tersebut, mereka memang membutuhkan waktu yang cukup lama namun dari hasil yang dilihat, mereka sudah tampak bahwa mereka telah memahami susunan kalimat yang benar.

c. Bidang Semantik

Tingkat pemahaman anak-anak tunarungu terhadap pembicaraan pengajar mengenai situasi disekelilingnya cukup baik, hal ini dikatakan oleh orang tua asuhnya yaitu Ibu Sherly. Adakalanya mereka sulit untuk memahami apa yang diucapkan oleh pengajar, maka mereka membutuhkan alat bantu berupa visual untuk membantu mereka dalam memahami yang dimaksudkan. Namun dapat dikatakan bahwa anak tunarungu memiliki daya tangkap yang normal dan mampu memberikan tanggapan yang baik apabila diajak berkomunikasi.

Pada aspek ini peneliti mempersiapkan sebuah gambar (Jerapah) yang memiliki leher panjang dan memiliki empat kaki. Maka peneliti siap mengajukan pertanyaan yang fungsinya untuk menimbulkan jawaban dari RM dan NWA. Contoh:

Apakah hewan ini jerapah?

Apakah hewan ini memiliki leher?

Apakah hewan ini berkaki empat?

Untuk mengetahui apakah mereka mampu memahami apa yang telah dikatakan pengajar maka mereka dilihatkan gambar jerapah dan mereka merespon dengan jawaban $\mathrm{RM}$ dan NWA, yaitu : jerapah, panjang, empat 
Peneliti mengharapkan respon yang lebih besar lagi dengan memberikan pertanyaan kepada mereka, seperti;

Peneliti : "Jerapah berkaki empat. Apakah manusia berkaki empat?"

RM dan NWA : "Manusia kaki empat (menunjuk kaki kiri, kaki kanan, tangan kiri, dan tangan kanannya)"

Dapat peneliti simpulkan bahwa dalam tingkat pemahaman sebuah makna dari nama-nama organ tubuh, mereka belum sepenuhnya memahami.

\section{PENUTUP}

Berdasarkan uraian yang telah dipaparkan pada bab-bab sebelumnya, peneliti dapat memberikan simpulan dari hasil penelitian yang berjudul "Pemerolehan Bahasa Anak Tunarungu Usia 12-15 Tahun di Panti Sosial Bina Rungu Wicara (PSBRW) Melati"

Hasil dari penelitian yang telah dilakukan, maka dapat ditarik kesimpulan bahwa

\section{REFERENSI}

Amin, Mohamad. 1991. Ortopedik Umum. Jakarta: Rineka Cipta.

Brown, H Douglas Brown. 2008. Prinsip Pembelajaran dan Pengajaran Bahasa: Edisi Kelima. Jakarta: Kedutaan Besar Amerika Serikat di Jakarta.

Chaer, Abdul. 2009. Fonologi Bahasa Indonesia. Jakarta: Rineka Cipta. 2009. Sintaksis Bahasa Indonesia. Jakarta: Rineka Cipta. 2009. Pengantar Semantik Bahasa Indonesia. Jakarta: Rineka Cipta.

Dardjowodjojo, Soenjono. 2014. Psikolinguistik. Jakarta: Yayasan Buku Obor Indonesia. pemerolehan bahasa anak tunarungu usia 12-15 tahun di PSBRW Melati meliputi bidang fonologi, sintaksis dan semantik yaitu 1) Mereka tidak dapat berucap dengan jelas yakni banyak bunyi konsonan yang diabaikan, 2) Ketika mereka menulis nama lengkap, secara tulisan mereka sudah jelas, 3) Mereka juga mampu untuk berhitung, membaca dan menyusun kalimat berdasarkan runtutan kalimat yang utuh, dan 4) Kemampuan mereka dalam memahami makna kata, masih terdapat kelemahan.

Diperoleh pula berbagai penemuan yang peneliti temui bahwa anak-anak tunarungu memiliki emosi yang tidak stabil meskipun usia mereka sudah berkepala tiga. Merasa tidak percaya diri membuat mereka merasa malu untuk bertemu dengan temantemannya namun hal ini tidak akan berjalan selamanya apabila mereka diberikan kepercayaan oleh orang tua kandungnya untuk berinteraksi secara normal. Dalam hal ini, peran orangtualah yang sangat penting dalam pemerolehan bahasa anak tunarungu.

Murni, Winarsih. 2007. Pendidikan Bahasa bagi Anak Gangguan Pendengaran dalam Keluarga. Jakarta : Direktorat Jendral Pendidikan Nasional.

Putranto, Bambang. 2015. Menangani Siswa yang Membutuhan Perhatian Khusus. Yogyakarta: DIVA Press.

Sardjono. 1997. Orthopaedagogiek Tunarungu I; Seri Pendidikan bagi Anak Tuna Rungu. Solo: UNS Press.

Somad dan Hernawati. 1996. Ortopedagogik Anak Tuna Rungu. Jakarta: Depdikbud. 